\title{
Teori Agenda Setting dalam Ilmu Komunikasi
}

\section{Theory of Setting Agenda in Communication Science}

\author{
Elfi Yanti Ritonga \\ Program Studi Komunikasi Penyiaran Islam, Fakultas Dakwah dan Komunikasi, \\ Universitas Islam Negeri Sumatera Utara, Indonesia \\ *Corresponding Author, Email: eyritonga@gmail.com
}

Abstrak

Teori agenda setting ini banyak dipakai dalam penelitian oleh para peneliti yang ingin mengukur pengaruh media bagi khalayak. Dua asumsi dasar yang paling mendasari penelitian tentang penentuan agenda setting adalah : 1) masyarakat pers dan mass media tidak mencerminkan kenyataan, mereka menyaring dan membentuk isu, 2) konsentrasi media massa hanya pada beberapa masalah masyarakat untuk ditayangkan sebagai isu-isu yang lebih penting daripada isu-isu lain. Kritik terhadap teori agenda setting ini sendiri sejalan dengan perkembangan zaman dan fenomena masyarakat, sudah bermunculan. Munculnya teori agenda setting memberikan kritik dengan menggambarkan bahwa manusia adalah pasif sehingga dalam mengendalikan lingkungannya agenda media berpengaruh terhadap agenda masyarakat.

Kata Kunci: Teori Agenda Setting, Media dan Khalayak.

\begin{abstract}
Setting agenda theory is widely used in research by researchers who want to measure the influence of media for audiences. The two most basic assumptions underlying the study of setting agenda setting are: 1) the press and mass media do not reflect reality; they filter and shape the issue; 2) the concentration of mass media is only on a few issues of society to serve as issues of greater importance than other issues. Critics of the agenda setting theory itself is in line with the development of the times and phenomena of society, already emerging. The emergence of the agenda setting theory provides a critique by describing that human is passive so that in controlling the environment agenda media influence on community agenda.
\end{abstract}

Keywords: Setting Agenda Theory, Media and Audiences.

How to Cite: Ritonga, E.Y., (2018), Teori Agenda Setting dalam Ilmu Komunikasi, SIMBOLIKA, 4 (1): 32 41. 


\section{PENDAHULUAN}

Komunikasi massa merupakan sumber kajian potensial yang memiliki bidang bahasan yang cukup luas dan mendalam, dan juga didukung oleh teori yang lumayan banyak jumlahnya. Hal ini bisa dipahami sebab ilmu komunikasi yang kita kenal sekarang ini, merupakan proses evaluasi panjang dari ilmu komunikasi massa, yang awalnya hanya dikenal sebagai ilmu media massa atau ilmu pers yang juga merupakan hasil elaborasi dari ilmu publisistik (ilmu persurat-kabaran) yang berpusat di Jerman dan ilmu Jurnalistik yang berbasis di AS (Arifin, 2006: 10). Baru dinamakan ilmu komunikasi pasca Perang Dunia II oleh para ilmuan Barat, tujuan utamanya adalah untuk mencover semua bidang kajian dalam komunikasi yang semakin luas dan berkembang.

Komunikasi massa sendiri kerap didefinisikan sebagai komunikasi melalui media massa (modern) pada awalnya hanya mencakup media cetak (surat kabar, majalah atau tabloid) dan media elektronik (TV dan radio), baru belakangan termasuk kajian multimedia yang juga sering disebut media dot com (internet). Pada era ini, kajian komunikasi massa berkembang menjadi semakin luas, selain mencakup tiga jenis media (media cetak, media elektronik, dan multimedia), peran dan proses komunikasi massa, juga efek media bagi masyarakat dan budaya, sehingga semakin banyak dijadikan sebagai objek studi (Mc Quail, 1987: 3)

Dalam tinjauan komunikasi massa, paling tidak teori-teori yang muncul dapat dikelompokkan ke dalam 4 (empat) bidang, yaitu teori-teori awal komunikasi massa, pengaruh komunikasi massa terhadap individu, pengaruh komunikasi massa terhadap masyarakat dan budaya, dan audiens pengaruhnya terhadap komunikasi massa (Liliweri, 2011: 884-892).

Teori Agenda Setting misalnya, masih saja sangat relevan hingga saat ini sekalipun dengan catatan-catatan tertentu harus dibubuhkan di sana, seperti pada masyarakat dan budaya seperti apa, atau pada kondisi kapan, dan seterusnya.

\section{PEMBAHASAN}

Jika diurai secara bahasa (etimologi) agenda setting diambil dari Bahasa Inggris yang terdiri dari dua suku kata, yakni agenda dan setting. Di dalam Kamus Besar Bahasa Indonesia (KBBI) kata agenda diartikan dalam 2 (dua) pengertian, yaitu: 1) buku catatan yang bertanggal untuk satu tahun: acara rapat itu telah dicatat dalam agenda; 2) acara (yang akan dibicarakan dalam rapat), hal itu tercantum juga dalam agenda rapat. Adapun kata mengagendakan, sebagai kata kerja (verb) berarti memasukkan dalam acara (rapat dan seminar) (http://blogilmukomunikasi.blogspot.co.id/20 13/12/teori-agenda-setting-komunikasi.html, 04.15).

Kata Setting atau yang dipadankan ke dalam Bahasa Indonesia dalam bentuk kata kerja (verb) dalam istilah "mengeset" diartikan sebagai pekerjaan menata, mengatur (tentang rambut, susunan huruf dalam mesin cetak, dan sebagainya): sudah menjadi kebiasaannya, ia mengeset rambut setiap pergi ke pesta, adapun orang yang mengerjakan pekerjaan mengeset dikatakan sebagai seorang "pengeset". Sementara itu, jika kata mengeset diubah menjadi kata "pengesetan" artinya menjadi "pengaturan" (http://adiprakosa.blogspot.co.id/2013/01/te ori-agenda-setting_1823.html, 03.15).

Berdasarkan pengertian secara etimologi di atas, maka pengertian agenda setting dapat dipahami sebagai pengaturan atau penyusunan agenda/acara/kegiatan. Hal ini sesuai dengan istilah yang dikemukakan oleh beberapa ahli komunikasi Indonesia sebagai penentuan atau penyusunan agenda. Lihat misalnya terjemahan dari pendapat Stephen W. Littlejohn dan Karen A. Foss dalam Hamdan, 2009: 415). Lihat juga Nuruddin, 2007: 195). 
Tentu saja yang dipahami dalam keterkaitannya dengan pembahasan ini adalah peran media massa dalam penyusunan agenda/acara/kegiatan seseorang.

Adapun pengertian agenda setting dalam istilah komunikasi adalah: a) Maxwell E. McCombs dan Donald L. Shaw percaya bahwa media massa memiliki kemampuan untuk mentransfer hal yang menonjol yang dimiliki sebuah berita dari news agenda mereka kepada public agenda. Pada saatnya, media massa mampu membuat apa yang penting menurutnya, menjadi penting pula bagi masyarakat. (Nuruddin, 2007: 195). b) Menurut Bernard C. Cohen agenda setting theory adalah teori yang menyatakan bahwa media massa berlaku merupakan pusat penentuan kebenaran dengan kemampuan media massa untuk mentransfer dua elemen yaitu kesadaran dan informasi ke dalam agenda publik dengan mengarahkan kesadaran publik serta perhatiannya kepada isu-isu yang dianggap penting oleh media massa. Dikemukakannya bahwa "pers mungkin tidak berhasil banyak waktu dalam menceritakan orang-orang yang berfikir, tetapi berhasil mengalihkan para pemirsa dalam berpikir tentang apa". (Baran dan Dennis, 2007: 13), c) Stephan W. Littlejohn dan Karen A. Foss mengemukakan bahwa agenda setting theory adalah teori yang menyatakan bahwa media membentuk gambaran atau isu yang penting dalam pikiran. Hal ini terjadi karena media harus selektif dalam melaporkan berita. Saluran berita sebagai penjaga gerbang informasi membuat pilihan tentang apa yang harus dilaporkan dan bagaimana melaporkannya. Apa yang masyarakat ketahui pada waktu tertentu merupakan hasil dari penjagaan gerbang oleh media (Littlejohn \& Foss, 2009: 416). d) Syukur Kholil mengutip pendapat Samsudin A. Rahim mengemukakan bahwa agenda setting adalah peran media massa yang mempunyai kekuatan untuk mempengaruhi pendapat dan perilaku masyarakat dengan menentukan agenda terhadap masalah yang dipandang penting (Kholil, 2007: 36).

Berdasarkan pengertian-pengertia di atas, dapat dikemukakan bahwa agenda setting theory membicarakan tentang peran besar media massa dalam menentukan agenda orang-orang yang terkena informasi tersebut. Masyarakat menjadi terbiasakan dengan berita-berita yang disampaikan media, sehingga menjadi bahan pembicaraan dalam pergaulan sehari-hari. Berita atau informasi yang disampaikan media tersebut bukan saja hanya sebagai ilmu atau pengetahuan bagi masyarakat, tetapi bahkan bisa mengubah gaya hidup, perilaku, ataupun sikap masyarakat.

Agenda setting theory (teori penyusunan agenda) mulai dirintis sejak tahun 1968, ketika berlangsungnya penelitian tentang kampanye pemilihan presiden Amerika Serikat. Penelitian ini berhasil menemukan hubungan yang tinggi antara penekanan berita dengan bagaimana berita itu dinilai tingkatannya oleh pemilih yang kemudian menjadi hipotesis teori agenda setting. Meningkatkatnya nilai penting topik tersebut bagi khalayak (Nuruddin, 2007: 195).

Hasil penelitian inilah yang kemudian menjadi fenomena utama bagi Maxwell McComb dan Donald L.Shaw dalam melahirkan teori agenda setting pada tahun 1972 (Lubis, 2007: 106). Yang dipublikasikan pertama kali dengan judul "The Agenda Setting Function of the Mass Media" Public Opinion Quarterly No. 37 (Bungin, 2006: 279).

Sebagai ilmuwan yang pertama sekali menguji teori ini, Maxwell McComb dan Donald L Shaw kemudian menjadi tokoh utama dibalik teori ini, yang empat tahun setelah penelitiannya (1968-1972) baru mengumumkan ke publik, bahwa risetnya itu menguatkan hipotesis hingga keduanya sepakat menamakan teori tersebut sebagai agenda setting theories.

Penelitian menjelang pemilu Presiden Amerika Serikat Tahun 1968 itu juga sekaligus 
menjadi latar belakang sejarah kelahiran teori agenda setting. Meskipun, jauh sebelumnya sudah ada gagasan/pandangan para ilmuan yang cenderung sama dengan fungsi teori agenda setting, sebagai hasil observasi pengaruh media terhadap khalayak. Hanya saja saat itu belum sampai memproklamirkan teori seperti teori agenda setting.

Aplikasi teori agenda setting pertama sekali pada penelitian perubahan sikap pemilih dalam kampanye pemilu Presiden AS tahun 1968, memberikan hasil penelitian berbalik dengan teori efek media terbatas (the limited media effect theories) sebelumnya. Dengan kata lain teori agenda setting menganggap media memiliki kekuatan untuk menarik perhatian dan mempengaruhi khalayak terhadap suatu isu. Fungsi teori ini berlangsung karena media sangat selektif dalam menyiarkan berita, yang menarik bagi publik baik dilihat dari aspek nilai berita (news value) maupun nilai jual (sell value). Sehingga model agenda setting ini mengasumsikan adanya hubungan positif antara penilaian yang diberikan media pada suatu persoalan dengan perhatian khalayak pada persoalan yang sama (Rahmat, 1993: 68).

Berdasarkan teori agenda setting, pemberitaan positif dan negatif media massa terhadap para kandidat selama massa kampanye akan sangat menentukan nasib kandidat dalam pemilu. Dengan demikian muncullah anggapan bahwa "menguasai media berarti menguasai publik" atau "menguasai media berarti menguasai massa (politik)". Jauh sebelum teori agenda setting diperkenalkan oleh McCombs dan Shaw, Bernard Cohen telah mengemukakan "pers lebih penting daripada sekedar penyedia informasi dan opini, barangkali mereka (media) tidak terlalu sukses dalam menyuruh apa yang dipikirkan seseorang tetapi mereka sukses dalam menyuruh orang apa yang seharusnya dipikir. Dunia akan terlihat berbeda menurut orang yang berbeda pula, tergantung bukan hanya pada visi mereka pribadi tetapi juga peta yang diberikan media massa kepada mereka (Stanley dan Dennis, 2007: 347).

Teori agenda setting merupakan salah satu dari sekian banyak teori tentang efek media massa bagi khalayak, baik yang termasuk kategori teori klasik seperti teori stimulus respon yang dikemukakan oleh Hovland, et al (1953) dan teori SOR (Stimulus Organisme Response) yang dikemukakan Melvin DeFleur (1970) sebagai modifikasi dari teori Stimulus Response sebelumnya, maupun yang masuk kategori teori kontemporer seperti teori Difusi Inovasi, teori Uses and Gratification, teori Defendensi Efek Komunikasi massa, teori Spiral of Silance, teori Uses and Effects, teori Spiral of Silence, teori Uses and Effect, teori The Limited Media Effects, The Bullet Theory atau teori Jarum Hipodermik, dan lain-lain.

Kehadiran teori Agenda Setting, telah membantah banyak teori sebelumnya seperti teori peluru (the bullet theory) yang dikemukakan Wilbur Shramm (1950-an), yang berasumsi efek media massa sangat luar biasa, karena khalayak bersifat pasif dan tidak berdaya, meskipun teori ini telah dibantah sendiri oleh Schramm pada tahun 1970 dengan meminta supaya teori peluru ajaib itu dianggap tidak ada, sebab ternyata khalayak media massa tidak pasif (Lubis, 2007: 124). Teori lain yang dibantah oleh teori agenda setting adalah teori media terbatas (the limited media effects) yang mengemukakan media massa hanya memiliki pengaruh sedikit terhadap khalayak.

Suatu studi yang dilakukan pada orangorang yang menonton dan tidak menonton perdebatan calon-calon presiden Amerika Serikat pada tahun 1976, peneliti dapat menunjukkan perbedaan dalam penentuan agenda di kalangan segmen-segmen khalayak yang spesifik. Di samping itu, Becker dan McLeod et al. (1979) ditunjukkan pula bahwa waktu memainkan peranan penting dalam 
proses tersebut. Sebagai perbandingan, suatu studi agenda setting surat kabar dan televisi di Barquisimeto, Venezuela oleh Chaffee dan Izcaray (1975) menunjukkan tiadanya efek yang diharapkan. Penggunaan media massa oleh responden kedua peneliti ini tidak mengarah pada meningkatnya salience untuk isu-isu yang menerima liputan media yang besar. Di sini tampak bahwa posisi sosial ekonomi responden memainkan peranan dalam menentukan kepentingan relatif beberapa isu publik (Sendjaja, 1993: 26).

Studi-studi ini menunjukkan bahwa agenda setting oleh media massa dapat terjadi dalam beberapa kondisi. Akan tetapi, kondisi yang berlaku di negara industri dan di negara sedang berkembang mungkin berbeda. Riset tentang agenda setting oleh media di negaranegara Dunia Ketiga masih perlu dilakukan, karena kebanyakan studi tentang agenda setting yang ada telah dilakukan di Eropa dan Amerika Serikat.

Di Indonesia, contoh fungsi agenda setting dalam pemberitaan media dan membawa pengaruh signifikan terhadap khalayak cukup banyak terjadi. Di Aceh misalnya, media mengcover penumpasan Gerakan Aceh Merdeka (GAM) sebelum Agustus 2005 atau perundingan GAM-RI setelah MoU Helsinki. Demikian juga berita seputar pemberantasan korupse, makelar kasus (markus), makelar pajak, maupun agenda lainnya berhasil mempengaruhi publik kita (Nuruddin, 2007: 196).

Dua asumsi dasar yang paling mendasari penelitian tentang penentuan agenda setting adalah : 1) masyarakat pers dan mass media tidak mencerminkan kenyataan, mereka menyaring dan membentuk isu, 2) konsentrasi media massa hanya pada beberapa masalah masyarakat untuk ditayangkan sebagai isu-isu yang lebih penting daripada isu-isu lain (Littlejohn \& Foss, 2007: 416).

Adapun agenda yang dapat ditentukan oleh media massa adalah: a) Apa yang harus dipikirkan oleh masyarakat; b) Menentukan fakta yang harus dipercayai oleh masyarakat; c) Menentukan penyelesaian terhadap suatu masalah ; d) Menentukan tumpuan perhatian terhadap suatu masalah; e) Menentukan apa yang perlu diketahui dan dilakukan masyarakat (Kholil, 2007: 36).

Stephen W. Littlejohn mengatakan, agenda setting beroperasi dalam tiga bagian sebagai berikut: a) Agenda media itu sendiri harus diformat. Proses ini akan memunculkan masalah bagaimana agenda media itu terjadi pada waktu pertama kali; b) Agenda media dalam banyak hal memengaruhi atau berinteraksi dengan agenda publik atau kepentingan isu tertentu bagi publik. Pernyataan ini memunculkan pertanyaan, seberapa besar kekuatan media mampu memengaruhi agenda publik dan bagaimana publik itu melakukannya; c) Agenda publik memengaruhu atau berinteraksi ke dalam agenda kebijakan. Agenda kebijakan adalah pembuatan kebijakan publik yang dianggap penting bagi individu (Littlejohn \& Foss, 2007: 416-417).

Aplikasi teori agenda setting dalam penelitian Chapel Hill, adalah sebuah penelitian sistematis pertama hipotesis penentuan agenda dilakukan oleh McCombs dan Shaw (1972). Pada dasarnya kedua pakar komunikasi ini tertarik untuk meneliti pendapat para pemilih menyangkut isu-isu yang dianggap penting sebagai hasil bentukan pemberitaan mengenai isu-isu tersebut. Mereka meneliti penentuan agenda dalam kampanye presiden tahun 1968 dan membuat hipotesis bahwa media massa menentukan agenda untuk setiap kampanye politik yang memengaruhi proyeksi sikap terhadap isu-isu politik.

Peneliti tersebut mewawancarai sampel yang terdiri dari 100 responden dan secara simultan melaksnaakan analisis isi media massa yang dapat diperoleh para pemilih ini dari lima surat kabar, dua majalah, dan dua tayangan berita malam jaringan televisi. Para peneliti ini mewawancarai seratus pemilih 
terdaftar yang belum memilih satu pun kandidat. Mereka melaksanakan penelitian mereka dengan berfokus pada pemilih yang masih ragu-ragu di Chapel Hill, North Carolina, karena pemilih "Ragu-ragu" seharusnya paling mudah terpengaruh dengan dampak penentuan agenda setting.

Para responden diminta untuk menyebutkan masalah-masalah utama di negara tersebut yang mereka lihat. Responsrespons ini diberi kode menjadi 15 kategori yang menggambarkan isu-isu utama dan juga jenis-jenis kampanye berita lain. Isi media berita yang berhubungan dengan pemilihan juga disortir ke dalam 15 kategori ini berdasarkan jumlahnya. Isi media berita juga dibagi menjadi kategori "utama" dan "ringan". Setiap responden diberikan sejumlah pertanyaan yang menggarisbawahi isu utama yang muncul ketika mereka melihatnya, tidak peduli apa yang akan dikatakan kandidat pasa saat itu. Lalu mereka kemudian membandingkan hasilnya dengan periodisasi waktu dan ruang menurut berbagai isu yang dihasilkan konten pada berita televisi, surat kabar dan majalah, dan halaman editorial yang tersedia bagi para pemilih wilayah tempat penelitian itu dilakukan. Hasil penelitian mereka selama bulan September dan Oktober pada pemilihan presiden tahun 1968 kemudian menemukan beberapa fakta yang mendukung berlangsungnya agenda setting media (Tamburak, 2013: 30-31).

Hasilnya kemudian ditulis Maxwell E. McCombs dan Donald Shaw dalam Baran bahwa media terlihat memberikan dampak yang cukup banyak terhadap subjek penelitian mengenai apa yang mereka anggap isu utama dalam pemilihan. Dengan adanya penelitian awal agenda setting di Chapel Hill yang dilakukan oleh McCombs dan D. Shaw, maka perspektif penentuan agenda media tidak hanya sebatas wacana yang berputar-putar di tengah lingkup aktivitas media selama ini, tapi yang paling penting mendapatkan pengakuan karena dapat dibuktikan secara empiris melalui penelitian mereka (Tamburak, 2013: 32).

Penelitian Charlotte adalah sebuah penelitian yang dibiarkan terbuka oleh penelitian agenda yang asli yang dilakukan oleh McCombs dan Shaw (1972) adalah pertanyaan mengenai urutan kausalitas. Penelitian Chapil Hill yang asli menemukan hubungan yang kuat antara media dengan agenda publik selama kampanye pemilihan tahun 1968, tetapi penelitian itu tak menunjukkan mana yang memengaruhi yang mana. Agenda media mungkin memengaruhi agenda publik, sebagaimana yang dinyatakan oleh hipotesis, tetapi agenda publik juga memengaruhi agenda media.

Sebagai langkah berikut mereka dalam mempelajari penentuan agenda, McCombs dan Shaw merencanakan penelitian tambahan yang berfokus pada kampanye pemilihan presiden tahun 1972. Penelitian ini ditetapkan di Charlotte, North Carolina. Penelitian ini menggunakan sampel yang lebih besar daripada penelitian Chapel Hill dan penelitian ini merupakan desain panel, dengan responden yang sama yang diwawancarai di beberapa titik selama kampanye. Salah satu tujuan spesifik penelitian ini adalah memperoleh bukti mengenai arah kausalitas penentuan agenda (Severin \& James, 2011: h. 266-268).

Sampel diambil dari pemilih yang sama secara random yang waktu pelaksanaan pada bulan Oktober ketika puncak kampanye dan bulan Nopember 1972 ketika pemilu digelar. Agar dapat melihat hubungan kausalitas para peneliti itu fokus pada dua periode, bulan Juni dan Oktober.

Dalam penelitian Charlotte kesimpulan hasil penelitian dibuat dalam bentuk tabel di mana kategori isu penting diurutkan dari yang paling penting hingga yang kurang penting. Isu perang Vietnam: (1) dianggap paling penting sehingga menempati peringkat pertama, disusul isu kerusuhan rasial, (2) kerusuhan kampus (3),... dan seterusnya. Nilai penting 
sebuah isu dalam penelitian ini berdasarkan banyaknya jumlah artikel yang dimuat dan banyaknya liputan yang dilakukan terhadap isu tersebut, sebagai contoh: isu perang Vietnam memiliki artikel berita dan liputan berita paling banyak.

Hasil penelitian tersebut menunjukkan peringkat yang diberikan oleh surat kabar terhadap isu perang Vietnam sama dengan peringkat yang diberikan oleh responden yaitu peringkat pertama, demikian juga dengan isu kerusuhan pada peringkat kedua. Namun, hasil terhadap isu lain cukup variatif, ada beberapa isu yang mengalami pergeseran seperti isu kerusuhan kampus yang tadinya berada pada peringkat ketiga (media massa) turun peringkat pentingnya menjadi peringkat keempat (responden), digantikan oleh isu kejahatan menjadi peringkat ketiga (menurut responden) yang sebelumnya berada pada peringkat keenam (liputan media massa).

Hasilnya, bahwa untuk setiap periode tersebut peneliti mendapati tingkat agenda media yang beragam dan diambil berdasarkan analisis isu surat kabar Charlotte dan tayangan berita malam di jaringan televisi $C B S$ dan $N B C$ yakni, berkaitan dengan isu-isu kepentingan seperti ditunjukkan tabel di atas. Data untuk masa dua periode penelitian tersebut kemudian diuji dengan teknik cross-lagged. Penelitian menunjukkan hasil bahwa isu-isu yang berpengaruh dari media hanya pada isuisu yang disajikan berita surat kabar saja (Tamburak, 2013: 34).

Dari perbandingan teknik uji crosslagged tersebut, yang penting diperhatikan adalah garis diagonal (persilangan) yang menunjukkan adanya indikasi korelasi kausalitas pada periode tertentu di bulan Juni dan Oktober oleh pemilih terhadap isu-isu kepentingan yang disajikan berita dalam surat kabar Charlotte. Pertanyaannya, korelasi manakah yang lebih besar?. Apakah korelasi antara agenda surat kabar pada paruh waktu pertama (1) dengan agenda pemilih paruh waktu kedua (2) ataukah agenda surat kabar pada paruh waktu kedua (2) dengan agenda pemilih pada paruh waktu pertama (1)?. Hasilnya menunjukkan isu-isu kepentingan yang disajikan surat kabar Charlotte pada bulan Juni sebagai agenda media paruh pertama (1) memiliki korelasi kausalitas dengan agenda pemilih pada paruh kedua (2) di bulan Oktober. Hasil penilitian bukan hanya membuktikan adanya hubungan, namun juga menggambarkan adanya hubungan tersebut secara jelas bahwa agenda media massa memiliki pengaruh dalam membentuk agenda publik (Tamburak, 2013: 35).

Di Indonesia, teori agenda setting kerap digunakan (diuji) dalam penelitian-penelitian untuk mengukur popularitas para kandidat Presiden tiap kali menjelang pemilu presiden, sejak tahun 2014 yang lalu. Lembaga survei seperti Lingkaran Survei Indonesia (LSI) selalu mempublikasikan hasil poolingnya yang mengejutkan, sebab mengalami perbedaan signifikan antara pooling pertama dengan pooling berikutnya selama masa kampanye (khususnya pemberitaan media), ini berarti hipotesis fungsi agenda setting kembali teruji (Hamdani, 2011: 223).

Selain itu juga, kasus pidato Anies Baswedan setelah dilantik sebagai Gubernur DKI Jakarta baru-baru ini menjadi kontroversi yang tengah ramai diperbincangkan di media sosial karena mencantumkan kata-kata pribumi. Hal yang menjadi heboh di media sosial adalah bagian pernyatan Anies yang berbunyi " dulu kita semua pribumi ditindas dan dikalahkan. Kini telah merdeka, kini saatnya menjadi tuan rumah di negeri sendiri. Jangan sampai Jakarta ini seperti yang dituliskan pepatah Madura. Itik telor, ayam singerimi. Itik yang bertelor, ayam yang mengerami.

Itu bunyi teks pidato yang dipegang Anies, yang disampaikan langsung Anies agak berbeda, ada sedikit penambahan kata-kata menjadi berbunyi dan Jakarta ini satu dari sedikit kota di Indonesia yang merasakan kolonialisme dari dekat. Selama ratus tahun, di 
tempat lain penjajahan mungkin tersa jauh. Tapi di Jakarta, bagi orang Jakarta kolonialisme itu di depan mata. Dirasakan sehari-hari, karena itu bila kita merdeka janjijanji harus dilunaskan. Dulu kita semua, pribumi ditindas dan dikalahkan. Kini telah merdeka, kini saatnya kita jadi tuan rumah di negeri sendiri. Jangan sampai Jakarta ini seperti yang dituliskan dalam pepatah Madura (Aghilfath 2017-10-17T11:57:27+07:00).

Dari kasus ini kita melihat bagaimana proses agenda setting berjalan, bahwa media massa mengarahkan "apa yang harus dipikirkan" oleh publik melalui penonjolan isu-isu (priming), dan membingkai (framing) pesan-pesan media. Mengapa hal ini disebut sebagai agenda setting, karena persoalan ini diangkat oleh media massa maka isunya menjadi nasional.

Kritik terhadap teori agenda setting ini adalah bahwa opini yang muncul di antara peneliti media adalah bahwa media tidak selalu memiliki pengaruh kuat dalam agenda masyarakat. Kekuasaan media bergantung pada faktor-faktor, seperti kredibilitas media terhadap isu-isu tertentu pada saat-saat tertentu, tingkat pertentangan bukti yang dirasakan oleh individu anggota masyarakat, tingkat dimana individu berbagi nilai media pada waktu-waktu tertentu, dan kebutuhan masyarakat Littlejohn dan Foss, Teori, h. 417. Hal ini sejalan dengan yang dikemukakan sebelumnya bahwa terdapat dua agenda yang menentukan berpengaruh atau tidaknya suatu media kepada khalayak, yaitu agenda media dan agenda publik itu sendiri.

Berdasarkan faktor-faktor tersebut, maka kritik terhadap teori agenda setting ini sendiri sejalan dengan perkembangan zaman dan fenomena masyarakat, sudah bermunculan. Adalah McChomb dan Shaw yang awalnya juga sebagai penggagas munculnya teori agenda setting memberikan kritik dengan menggambarkan bahwa manusia adalah pasif sehingga dalam mengendalikan lingkungannya agenda media berpengaruh terhadap agenda masyarakat. Jika dihubungkan dengan limited effect theories, pengaruh media atas publik tidak sebesar yang diperkirakan. Ada halangan yang menghambat peran media atas publik, seperti tingkat intelektualitas, pendidikan agama, norma keluarga dan sebagainya.

Banyak kritik dilontarkan, yang mempertanyakan dimanakah perbedaan substansial antara efek media dimasa lalu dengan aplikasi pendekatan agenda setting dalam menjelsakan sifat danderajad efek media terhadap audiens. Dalam model tersebut, realita yang mengarah pada hubungan timbal balik antara agenda media dan agenda publik kurang mendapatkan perhatian. Seringkali terlupakan bahwa framing dan priming agenda media, dan tingkat kemenonjolan (salience) isu/kejadian pada agenda publik, merupakan proses tidak berujung dan tidak berpangkal. Kurang perhatian terhadap proses baik dalam bentuk agenda media maupun menjelaskan mengapa isu-isu tertentu, yang disiarkan oleh media tertentu mempunyai pengaruh, bagi audiens tertentu (Nuruddin, 2007: 198).

Respon terhadap kenyataan tersebut adalah terjadinya perubahan orientasi dalam studi agenda bahwa agenda setting bukan hanya suatu gejala melainkan sebuah proses yang berlangsung terus menerus (on going process). Berdasarkan perspektif ini, pemenuhan (coverage variabel dalam studi agenda setting menjadi sangat luas, karena melibatkan faktor-faktor yang merupakan bagian dari proses terbentuknya agenda media dan agenda publik dan sekaligus bisa digunakan untuk menjelaskan mengapa efek media sangat besar, kecil, atau tidak ada sama sekali.

Kekuatan teori agenda setting adalah: 1) Khalayak bukan saja belajar tentang isu-isu masyarakat dan hal-hal lain melalui media, mereka juga belajar sejauhmana pentingnya suatu isu atau topik dari penegasan yang diberikan oleh media massa. Misalnya, dalam 
merenungkan apa yang diucapkan kandidat selama kampanye, media massa tampaknya menentukan isu-isu yang penting. Dengan kata lain, media menentukan "acara"(agenda) kampanye. 2) Dampak media massa, kemampuan untuk menimbulkan perubahan kognitif di antara individu-individu, telah dijuluki sebagai fungsi agenda setting dari komunikasi massa. Di sinilah terletak dari efek komunikasi yang terpenting, kemampuan media untuk menstruktur dunia buat kita. Tapi yang jelas agenda setting telah membangkitkan kembali minat peneliti pada efek komunikasi massa (Ritonga, 2011: 612).

Adapun kelemahan teori agenda setting adalah 1) Mayoritas berita yang ditayangkan hanya menguntungkan si pemilik modal. Sebagai contoh, jika kita melihat beberapa acara media massa seperti TV ONE dan Metro TV, kesan-kesan masa kampanye pilpres 2014 masih cukup terasa, sehingga masyarakat juga sangat terpengaruh dengan keadaan tersebut. Masyarakat secara otomatis ada keengganan untuk menonton saluran yang mereka anggap tidak berpihak dengan keinginan mereka, begitu juga dengan media cetak. 2) Selain dari itu teori agenda setting ini juga berperan bagaikan pengadilan. Karena teori ini menganggap bahwa apa yang mereka beritakan itu adalah sebuah kebenaran padahal belum tentu seperti itu, sebab dalam proses kerja teori ini tidak ada istilah konfirmasi, yang ada hanya mendengarkan dari sepihak. Padahal seyogyanya dalam menyampaikan sebuah informasi media harus bersikap netral sehingga tidak terjadi kesalahan dalam menentukan keputusan atau pun kebijakan.

Bila kita melihat dengan kacamata Islam, merupakan suatu keharusan bagi setiap individu maupun masyarakat untuk melakukan konfirmasi terhadap informasi yang mereka terima, terlebih bila si komunikator seorang yang kredibilitasnya masih dipertanyakan (fasik). Hal ini secara tegas dinyatakan Allah dalam firman-Nya Q.S Al-Hujarat: 6.

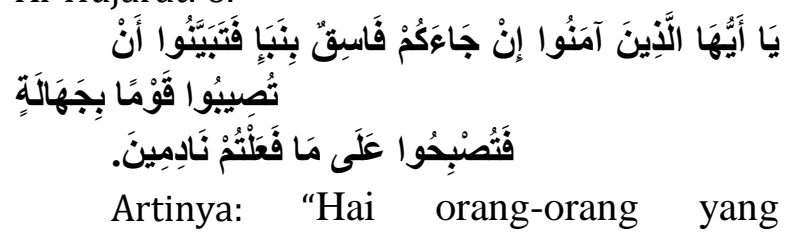
beriman, jika datang kepadamu orang fasik membawa suatu berita, maka periksalah dengan teliti agar kamu tidak menimpakan suatu musibah kepada suatu kaum tanpa mengetahui keadaannya yang menyebabkan kamu menyesal atas perbuatanmu itu." (Departemen Agama RI, 2005: 516).

\section{SIMPULAN}

Teori agenda setting pertama kali dikemukakan oleh Walter Lippman pada konsep "The World Outside and The Picture in Our Head" yang sebelumnya telah menjadi bahan pertimbangan oleh Bernard Cohen dalam konsep "The mass media may not be successful in telling us what to think, but they are stunningly successful in telling us what to think about". Penelitian empiris ini dilakukan Maxwel E. McCombs dan Donald L. Shaw ketika mereka meneliti pemilihan presiden tahun 1972. Mereka mengatakan, walaupun para ilmuan yang meneliti perilaku manusia belum menemukan kekuatan media seperti yang disinyalir oleh pandangan masyarakat yang konvensional, belakangan ini mereka menemukan cukup bukti bahwa para penyunting dan penyiar memainkan peranan yang penting dalam membentuk realitas sosial kita. Itu terjadi ketika mereka melaksanakan tugas kesehariaan mereka dalam menonjolkan berita. Khalayak bukan saja belajar tentang isu-isu masyarakat dan hal-hal lain melalui media, mereka juga belajar sejauh mana pentingnya suatu isu atau topik dari penegasan yang diberikan oleh media massa. Dua asumsi dasar yang paling mendasari penelitian tentang penentuan agenda setting adalah : 1) masyarakat pers dan mass media tidak mencerminkan kenyataan, mereka 
menyaring dan membentuk isu, 2) konsentrasi media massa hanya pada beberapa masalah masyarakat untuk ditayangkan sebagai isu-isu yang lebih penting daripada isu-isu lain. Teori agenda setting ini banyak dipakai dalam penelitian oleh para peneliti yang ingin mengukur pengaruh media bagi khalayak. Kritik terhadap teori agenda setting ini sendiri sejalan dengan perkembangan zaman dan fenomena masyarakat, sudah bermunculan. Adalah McChomb dan Shaw yang awalnya juga sebagai penggagas munculnya teori agenda setting memberikan kritik dengan menggambarkan bahwa manusia adalah pasif sehingga dalam mengendalikan lingkungannya agenda media berpengaruh terhadap agenda masyarakat. Jika dihubungkan dengan limited effect theories, pengaruh media atas publik tidak sebesar yang diperkirakan. Ada halangan yang menghambat peran media atas publik, seperti tingkat intelektualitas, pendidikan agama, norma keluarga dan sebagainya.

\section{DAFTAR PUSTAKA}

Arifin, A., (2006), Ilmu Komunikasi; Sebuah Pengantar. Jakarta: Raja Grafindo Persada.

Bungin, B., (2006), Sosiologi Komunikasi. Jakarta: Kencana Prenada Media Group.

Departemen Agama RI, (2005), Alquran dan Terjemahnya. Bandung: CV. Penerbit JART.

Hamdani. (2011), Teori Agenda Setting. Teori Komunikasi Massa. Medan: Cita Pustaka Media Perintis.

Kholil, S.. (2007), Komunikasi Islami. Bandung: Citapustaka Media.

Liliweri, A., (2011), Komunikasi: Serba Ada Serba Makna. Jakartta: Kencana.

Lubis, S., (2007), Teori-teori Komunikasi (sebuah konsepsi, Analisa dan Aplikasi) Medan.

Nuruddin. (2007), Pengantar Komunikasi Massa. Jakarta: Raja Grafindo Persada.

Quail, Mc D., (1987), Teori Komunikasi Massa. Jakarta: Penerbit Erlangga.

Rahmat, J., (1993), Psikologi Komunikasi. Bandung: Remaja Rosdakarya.

Sendjaja, S.D., (1993), Teori Komunikasi. Jakarta: UT.
Stanley J.B., dan K. Dennis D., (2007), Teori Komunikasi Massa (terj) Jakarta: Salemba Humanika.

Littlejohn, S.W. dan Karen A.F., (2009), oleh Mohammad Yusuf Hamdan, Theories of Human Communications, 9 th ed Teori Komunikasi. Jakarta: Salemba Humanika.

Tamburak, A., (2013), Agenda Setting Media Massa. Jakarta: PT RajaGrafindo Persada, cet. 2.

Severin, W.J., \& James W.T.,Jr., (2011), Teori Komunikasi: Sejarah, Metode, dan Terapan Di Dalam Media Massa. Jakarta: Kencana, cet. 5 .

Ritonga, H.J., (2011). Teori Agenda Setting. Jurnal Akademika Volume II Nomor 6, Medan: LPPI-SHA

aghilfath 2017-10-17T11:57:27+07:00.

http://blogilmukomunikasi.blogspot.co.id/2013/12 /teori-agenda-settingkomunikasi.html,04.15

http://adiprakosa.blogspot.co.id/2013/o1/teoriagenda-setting_1823.html, 03.15 